\title{
THE BRITISH COUNCIL'S EDUCATIONAL ENTERPRISE IN EGYPT AFTER THE SUEZ CANAL CRISIS: A REBIRTH OF ANGLO- EGYPTIAN LINKS
}

\author{
Malika Sahel $^{1}$ \\ ${ }^{1}$ Senior Lecturer, Department of English, EcoleNormaleSupérieure/Bouzaréah (E.N.S.B), Algiers, Algeria
}

\begin{abstract}
Developments and changes of policy and opinion in both Britain and Egypt during the 1960's, offered the British Council an opportunity to attempt the restoration and improvement of its local standing overseas particularly in Egypt, a very influential Arab country, as it was before the Suez Canal Crisis (1956). The Egyptian authorities identified the teaching of the English language as a first priority because it was perceived as a prerequisite means of communication with the world. Thus, the educational field was announced as the main available field for the British Council's action, at a time instability in the AngloEgyptian political relations prevailed. For instance, in 1961 full diplomatic relations between the two countries were resumed by Egypt.
\end{abstract}

Keywords: Egypt, British Council, Educational Enterprise, Teaching, Anglo/Egyptian Links. $* * *$

\section{INTRODUCTION}

The renewal of the British Council operation in Egypt dated from the summer of 1959 when the Egyptian Government manifested his welcome of certain forms of scientific and educational assistance. Could an expansion in the Council's educational work provide once again a substantial contribution to the improvement and strengthening of Anglo/Egyptian relations ? Was this possible at a time Britain's alignment with Israel damaged the British image and position in the middle East in general and in Egypt in a more particular way?

The current paper examines the British Council's main educational activities in Egypt, namely the English language teaching, interchange of professionals and the supply of British books, to find out the extent to which the Council's educational exerted influence was able to restore British standing in this very influential Arab country, Egypt.

Before considering the British Council's policy in Egypt, it is worth starting with a historical background to show how the Council's successful cultural and educational enterprise in Egypt before the Suez Canal crisis greatly assisted British position there.

\section{HISTORICAL BACKGROUND: THE BRITISH} \section{COUNCIL'S POSITION IN EGYPT BEFORE} 1956

The Council was established between the two world wars, in 1934. It is worth noting that its first overseas established office in1939 was, particularly, in Egypt. The latter's association with Lord Lloyd in the early days of the Council's history and the very dynamic nature of the
Council's work in Egypt during and immediately after the Second World War, distinguished this Arab country in a rather single way.[1]In this context, I. H. Williams, the then British Acting Representative in Egypt, stated in 1961 that even at that time 'more Council staff [had] worked in Egypt than in any other single country'.[2]

Indeed, the period between 1939 and 1956 witnessed the British Council's cultural activities' growth. English culture and language became deeply ingrained among the educated classes, a fact that greatly helped British standing and influence in this strategic Arab country. However, this Council's successful period of dynamism in Egypt was drastically and finally ended by the events of 1956. Indeed, the Suez Canal crisis even had a serious effect on the Council's new period in Egypt which began effectively early in 1960. In this respect, I. H. Williams pointed out :

Permanent Council work began with my arrival in Cairo at the end of February 1960, and an office was opened in furnished accommodation in the middle of April. The only salvage from the wreck of 1956 was three rather battered wooden cupboards.[3]

On the $2^{\text {th }}$ July 1956, the Egyptian Government nationalized the Suez Canal. This courageous initiative provoked a growing tension in the Middle East. The Israeli army attacked the Egyptian on the $29^{\text {th }}$ October 1956 in the Sinai Peninsula. The refusal of a British and French ultimatum by Egypt led to a combined British and French attack on Egypt on the $1^{\text {st }}$ November of the same year.[4] Obviously, this attack provoked official hostilities towards Britain, a fact that weakened the Anglo/Egyptian relations. The latter even worsened in the early 1960's because of the Rhodesian Question, another issue which provoked the anger of the 
Organisation of African Unity.[5] Consequently, in December 1961, Egypt broke her diplomatic relations with Britain.[6]

For a great many Egyptians the Suez crisis came to mean two essential things - among others : the final discrediting of any British claims to a privileged position in Egypt and a proof that this Arab country, with a large part of world opinion behind her, was able to stand up to all comers. It is remarkable how the crisis of 1956 penetrated deeply into the national consciousness in Egypt as it did in Britain. But whereas the tendency in Britain was to forget the issue, in Egypt it became a source of national proud and historical lessons to teach to future generations.

There is no doubt that Egypt of the 1960s was the most highly populated and remained the most influential of the Arab countries. Therefore, it was very important for the British Council to attempt building what the events of 1956 damaged. Although the continually uncertain climate of political relations between Egypt and the United Kingdom limited the field of co-operation to culture and technical assistance, the British Council did not mince efforts to project a new and positive image of Britain in Egypt.[7]

\section{POLICY AND OBJECTIVES}

The British Council's policy in Egypt was to attract the relevant Egyptian authorities in every educational or cultural field available. It had to establish more effective working procedures and to agree on priorities in different fields of mutual advantage. For instance, they had to agree on the choice of Egyptians to visit Britain, the choice of Britons to visit Egypt, and the availability of the British books and periodicals which Egypt required most urgently.[8]

The Council's priority was to obtain a separate corporate existence for itself and premises of its own from which all normal Council operations could be conducted. Besides, it had to co-ordinate its expanding activities with the actual needs and requirements of the relevant Egyptian institutions.[9] As to its long-term objectives, the Council had to restore its local standing as it was before 1956, to cooperate with Egypt in overcoming 'the results of ... cultural isolation' political and economic events imposed for years, a fact that harmed Anglo-Egyptian relations and British Council precious previous achievements in Egypt. Besides, the Council aimed at clarifying that it was a British government's agent in all educational spheres. Thus, it kept its position as the Cultural Section of the British Embassy.[10] This Council's attitude meant to avoid provoking suspicion during this critical period among the Egyptians who preferred "frank dealing" according to the Council's words.

\section{THE BRITISH COUNCIL'S EDUCATIONAL POSITION IN EGYPT DURING THE 1960S}

The Egyptians' interest in British higher Education continued to be striking. Britain remained the favourite country of the young Egyptian doctor, and the government appeared to be increasing the number of medical graduates sent to the United Kingdom. Besides, the industrialization of the country offered other opportunities for training in Britain in management subjects.

On the technical side, the West Germans prevailed. Large share in the industrialization of Egypt had been matched by their great efforts in the field of technical education and training. This important field provoked a serious competition which the Council decided to win for Britain. In this respect, the British Council's Annual Report for 196061 , pointed out: '... more can be done in the future to satisfy the demands of U.A.R. engineers and engineering students for training in Britain'.[11] In fact, the Council's absence in Egypt for few years (1956-59) not only allowed the West Germans to dominate the technical side of higher education in this important country, but also caused its loss of the ground of English Language Teaching in the Schools, Training Colleges and Universities to the Americans. For instance, the Council found difficulties to appoint British lectures to the Cairo University Department of English in 1960.

However, the Higher Teachers Training Colleges, which came under the direct control of the Executive Ministry of Education, was a more open field for Council's action in view of the huge increasing number of Egyptians being schooled and the absence of sufficient numbers of qualified Egyptian teaching staff to fill the empty needed posts. Thus, steps to recruit British lecturers in English for these institutions took place and the following years witnessed some British lecturers in post as will be detailed in the section devoted to English language teaching operation. Many Egyptian teachers of English in the secondary schools were looking for summer schools in the United Kingdom. For instance, in 1961, the Ministry of Education was offered financial assistance to allow them to go to United Kingdom summer schools, but exit visas were granted only to very few of these teachers.[12]

The loss of the British Council library in 1956 was seriously felt. Thus, the establishment of a new one during the 1960s could satisfy not only the specialist but also the general reader, who was badly served by the bookshops. The Council started its close contact with booksellers and the significant number of representatives of British publishers who had been through Cairo during 1960.

Another educational matter the Council considered was the interchange of professionals. The many specialists both Council - sponsored and others, who had visited Egypt, had been significantly worth. Personal contact was very important and visitors from outside were particularly valuable among Egyptians, who were, either for political or currency problems, restricted during the years following the Suez crisis. For instance, the largest single group of visitors had been medical and the British Council wished a stronger representation in some other fields such as social sciences.[13]Thus, the British Council found a fertile ground 
to cultivate important links that would serve its long as well as short-term objectives.

However, the Egyptian television which began in July 1960 to spread awareness among Egyptians was to limit the British participation in educational and cultural programmes. Consequently, the Council selected the indirect approach to avoid suspicion without disregarding the opportunities. For instance, enquiries about English teaching films for television were already received in 1960.[14]

\subsection{English Language Teaching}

Much more importance was being attached to raising standards of foreign language teaching, particularly English. The Egyptian growing need for a better knowledge of English was continually manifested during the 1960s. For instance, $95 \%$ of secondary school pupils were studying English in a traditional way: using ancient methods and text books.[15] Therefore, the British Council assistance in the field of English language teaching remained greatly sought. For instance, in 1962-63 a Council's opening up in the field of English Language teaching was registered as a remarkable event. Since 1962, the Council had a British lecturer in a key post at the Higher Teachers' College at Heliopolis. Such appointment allowed the Council to exert some influence on the training of teachers of English going into the Government preparatory (which means lower secondary) schools, where English teaching was introduced in the Egyptian educational system.[16]

Thus, English language teaching remained the most important single aspect of British Council's work in Egypt. The Council multiplied its efforts to satisfy the enormous demand of the Egyptians for English language tuition.

Another Council's interesting start was encouraged by the Egyptian Ministry of Education in the summer of 1962. The British Council provided two lecturer/tutors at a Summer School in Cairo for secondary school teachers of English. In this context, the British Council pointed out: 'This was the first time the British Council had participated in a Summer School for many years'[17]This assistance was appreciated and was followed by other similar and different ones during the following years.

The British Council increased its help to the Ministry of Education in training their teachers of English. For instance, in August 1963, 2 lecturers were brought from Britain for a very successful summer school at Alexandria, and 10 senior teachers were sent to Britain for short courses. The British Council wholly financed these visits which could only strengthen its efforts in English language teaching. The following year (1964) witnessed an increase in the number of teachers sent to Britain which reached 24.[18] The cost of these organised training was started with the Ministry of Education.[19]

Thus, during the first half of the 1960s, the Council most significant effort to improve English teaching in the government schools was through Summer Schools, both in Egypt and Britain. For instance, in 1964, the Council again provided the Ministry of Education with two visiting lecturers from Britain for its Summer School in Alexandria, and one of the British Council resident School Teachers was also present to assist in leading discussions and group work. This Summer School, which began in 1962 on the British Council initiative flourished by attracting more teachers and inspectors of English each year. The membership in 1964-65 reached 150.[20]

In addition to Summer School courses, the British Council provided English Language teaching in schools, universities, training colleges and centres of in-service training through its subsidized staff. It carried on supporting English teaching in three of the former British Schools : El Nasr College Maadi, with Mr. J. J. Barnett on secondment from the Council ; El Nasr College Alexandria, with Miss I. E. Parker (Formula) and Mr. P. Callagan (Council recruited) ; and the El Nasr Boy's School, with J. G. Speed (Formula). In Alexandria University two subsidized posts in the English Department were filled, by Dr. L. Knight, who was already on the staff of the Department, and by Mr. A. L. Hall.[21]

Thus, by 1965-66, the British Council succeeded to have 6 Council-subsidized English teaching posts; one of these was at Ain Shams University. 2 more were recruited for Alexandria University. By July, the Council's established Language Unit at Alexandria University began its first course.[22] Its success imposed the recruitment of other English language specialists. For instance, in August 1969, one was appointed in Alexandria.[23] Later other posts were created, a fact that offered the Council a valuable opportunity to make the greatest contribution in the English Language field in Egypt. Henceforth, spread British ideas and exert influence in favour of Britain.

Before significantly increasing the number of the Council's appointed English Language specialists in Egypt, the Council had given high priority to the provision of visual aid equipment such as Language laboratories to back up the work of its existing teaching staff. Moreover, special care was devoted to improve the supply of British books and reading material with which their work would have remained uncompleted.

\subsection{Library and Books}

As soon as the renewal of its work was welcomed by the Egyptian Government, the British Council made close contacts with booksellers and with a significant number of representatives of British publishers who had been through Cairo during the year.[24] A remarkable improvement was noticed in the supply of British books in 1960 . However, it took to the Council more than two years to get its library ready for opening. Thus, the Council's most essential new development happened in March 1963 although the rapid increase in already established work was significant.[25]

The British Council's library work in Egypt knew continual development throughout the 1960s. For instance, the first 
half of 1964-65 witnessed normal progress : a steady increase in membership and in numbers of books issued as testified by I. H. Williams.[26] But, the beginning of the Academic year in October provoked a striking improvement. Egyptian University students constituted the largest group of the new British Council's Library members. Thus, the library started a new active phase, a fact that required more staff. Besides, several improvements were made to keep the reputation as the best foreign library in Cairo.

Moreover, the Council did not miss any occasion to make its library better known to both Egyptians and foreign residents. For instance, the locally-organised Shakespeare Exhibition opened at the end of April 1964, stood as one of the numerous occasions. Some months before the exhibition, the Council invited Foreign and Commonwealth embassies 'to lend contributions in the shape of translations of plays, records of productions of plays in their countries, works of criticism ...'. [27] Such initiative resulted in a most varied international collection of exhibits which showed a great interest in Shakespeare. In this context, it was stated :

Several eastern European countries submitted large contributions, particularly of photographs of local productions, and the Canadian exhibit, mainly of photographs and costume drawings from Stratford ... was particularly good.[28]

This exhibition's centre-piece offered a model of an Elizabethan theatre, M. R. S. Neilson, the British Council Lecturer at the Cairo Higher Teachers' College, beautifully worked.[29]

- $\quad$ [1] For details see : F. Donaldson's The British Council : The first Fifty Years, London, Jonathan Cape, 1984.

- [2] BW 29/75, Confidential, 'The British Council United Arab Republic Representative's Annual Report 1960-61', April, 1961, p. 1.

- [3] Ibid.

- $\quad$ [4] M. Pearce and G. Stewart, British Political History 1867-2001. Democracy and Decline, London \& New York, Rutledge, 2002, p. 629.

- [5] BW 29/75, Confidential, 'The British Council United Arab Republic Representative's Annual Report 1965-66', 1966, p. 1.

- [6] D. Butler and G. Butler, British Political Facts 19001994, United Kingdom, Macmillan, 1994, p. 484.

- [7] BW 29/75, Confidential, From British Embassy Cairo to Foreign and Commonwealth Office, London, S.W.1, 11 June 196, p.2.

- [8] BW 29/70, Restricted, The British CouncilArab Republic of Egypt, Representative's Annual Report 1972-73.

- [9] BW 29/70, Restricted, The British Council Arab Republic of Egypt, Representative's Annual Report 1971-72.

- $\quad$ [10] BW 29/70, op. cit, 1972-73.

- [11] BW 29/75, Confidential, The British Council United Arab Republic Annual Report 1960-61, 1961, p. 5.
- [12] Ibid, p. 6.

- [13] Ibid.

- [14] Ibid.

- [15] BW 29/75, Confidential, The British Council United Arab Republic Annual Report 1965-66, 1966, p. 2.

- [16] BW 29/75, Confidential, The British Council United Arab Republic Annual Report 1962-63, 1963, p. 3.

- $\quad$ [17] Ibid, p. 4.

- [18] BW 29/75, Confidential, The British Council United Arab Republic Annual Report 1964-65, 1965, p. 6.

- [19] BW 29/75, Confidential, The British Council United Arab Republic Annual Report 1963-64, 1964, p. 3.

- $\quad$ [20] BW 29/75, op. cit, 1965.

- [21] BW 29/75, Confidential, The British Council United Arab Republic Annual Report 1966-67, April 1967, Appendix A- Education, p. 1.

- [22] BW 29/75, op. cit, 1966, p. 3.

- $\quad$ [23] BW 29/75, op. cit, 11 June 1969.

- [24] BW 29/75, op. cit, 1961, p. 6.

- [25] BW 29/75, op. cit, 1963, p. 3.

- [26] BW 29/75, op. cit, 1965, p. 2.

- [27] Ibid.

- [28] Ibid, p. 3.

- [29] Ibid.

\section{CONCLUSION}

The British Council was conscious about the unlimited effect which its educational enterprise in Egypt inevitably could have on other Arab countries. For instance in May 1969, the Cairo press reported that Algeria asked for 500 more Egyptian teachers for Algerian schools making a total to about 1500 . Many more Egyptian teachers were also sent to Libya, Kuwait, Sudan and the Persian Gulf. Indeed, the total number of Egyptian teachers either officially sponsored or privately engaged in 1969 abroad was between 5000 and 6000. Thus, the British Council's exerted influence on the Egyptian educational system extended Egypt to include the Arab world in a more general way. This led to the potential value to British exports of accustoming Egyptian teachers to British ideas, methods and equipment. An Egyptian teacher trained on British books and equipment was likely to persuade Arab governments to equip their schools from the same source, thereby profiting both British business and disseminating British ideas. Thus, the British damaged image could be improved and Anglo-Arab relations were made healthier by the British Council's educational enterprise particularly through the teaching operation which allowed contact with the maximum of people who were to play a leading role in their respective countries' administrative, political, economic and social spheres during their professional careers. 


\section{REFERENCES}

[1]. BW 29/70. The British Council,(1972). Restricted.The British Council Arab Republic of Egypt. Representative's Annual Report 1971-72.

[2]. BW 29/70. The British Council, (1973).Restricted.The British Council Arab Republic of Egypt. Representative's Annual Report 1972-73.

[3]. BW 29/75. The British Council, (1961).Confidential. The British Council United Arab Republic Representative's Annual Report 1960-61.

[4]. BW 29/75. The British Council, (1966).Confidential. The British Council United Arab

Republic Representative's Annual Report 1965-66.

[5]. BW 29/75. The British Council, (1969).Confidential. From British Embassy Cairo to Foreign and Commonwealth Office, London, S.W.1.

[6]. BW 29/75. The British Council, (1961).Confidential. The British Council United Arab Republic Annual Report 1960-61.

[7]. BW 29/75. The British Council, (1963).Confidential. The British Council United Arab Republic Annual Report 1962-63.

[8]. BW 29/75. The British Council, (1964).Confidential. The British Council United Arab Republic Annual Report 1963-64.

[9]. BW 29/75. The British Council, (1966).Confidential. The British Council United Arab Republic Annual Report 1965-66.

[10]. BW 29/75. The British Council, (1965).Confidential. The British Council United Arab Republic Annual Report 1964-65.

[11]. BW 29/75. The British Council, (1967).Confidential. The British Council United Arab Republic Annual Report 1966-67. Appendix A- Education.

[12].Buther D. and Buther G., (1994). British Political Facts 1900-1994. United Kingdom, Macmillan.

[13]. Donaldson F., (1984). The British Council : The First Fifty Years. London : Jonathan Cape.

[14]. Pearce M. and Stewart G., (2002). British Political History 1867-2001. Democracy and Decline. London \&New York : Rutledge.

\section{BIOGRAPHY}

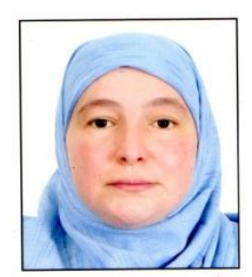

Dr. Malika SAHEL is a Senior Lecturer of British Civilization in the Department of English at the 'EcoleNormaleSupérieure of Bouzaréah (E.N.S.B) in Algiers/Algeria. 